NOTICE: this is the author's version of a work that was accepted for publication in Teaching and Teacher Education (ISSN 0742-051X). Changes resulting from the publishing process, such as peer review, editing, corrections, structural formatting, and other quality control mechanisms may not be reflected in this document. Changes may have been made to this work since it was submitted for publication. A definitive version was subsequently published in Teaching and Teacher Education (2012), 26 (3). pp. 630638. DOI: http://dx.doi.org/10.1016/j.tate.2009.09.011.

\title{
Enhancing the role of the arts in primary pre-service teacher education
}

\begin{abstract}
This research sought to explore the impact upon pre-service teachers' orientations towards the arts of a performing arts week within a one-year postgraduate teacher education programme. There is evidence from a range of data collected before, during and after the week that it had helped to strengthen participants' self-image as artistic individuals who recognise the value of the arts in children's education and have enhanced confidence in working with different professionals to teach the arts in a cross-disciplinary way. Within a climate of compliance, this study suggests that pre-service teachers require such experiences to overcome their fear of curriculum innovation.
\end{abstract}

\section{Keywords}

Arts; primary; pre-service teacher education; cross-curricular; teacher attitudes; cultural centres

\section{Introduction}

Higher Education the Arts and Schools (HEARTS) is a project established in 2004 to address a perceived deficit in training teachers to teach the arts within the primary curriculum (for pupils aged 5-11) in England. In the context of this study, we have taken the arts to comprise the disciplines of dance, drama, music and visual arts, which Downing et al. (2003) identified as the aspects of the curriculum regarded by primary teachers as falling under this heading. Findings from surveys of primary initial teacher education (ITE) (Rogers, 1998, 2003) and primary schools (Downing et al., 2003) suggested that the time allocated to the arts within one year Postgraduate Certificate of Education (PGCE) courses was small - typically between four and 12 hours - and that beginning teachers felt inadequately prepared to teach this area of the primary curriculum. In response to these findings, two UK-based arts education charities offered funding for a series of pilot projects to demonstrate and stimulate innovation in the arts within training programmes. Administered by the National Foundation for Educational Research (NFER), three providers of primary ITE were funded in 2004-5, a further three in 2005-6 and a final cohort of six in 2007-8, including the project that will form the basis of this study. 
The lack of preparation for teaching the arts in primary ITE can be linked to increased UK government control of the training curriculum, assessment and quality assurance procedures over a number of years. For example, the Department for Education and Employment (DfEE) Circular 4/98 (DfEE 1998) required programmes of primary ITE in England to follow a tightly prescribed curriculum in the subject areas of English, mathematics and science, specifying minimum numbers of hours to be allocated to each of these 'core' elements. The inspection framework enforcing compliance with this requirement and initially focusing exclusively on training in English and mathematics (TTA/OfSTED 1998) arguably had the effect of narrowing the curricula in primary PGCE programmes, thus reducing the attention given to the arts. The increase in schoolbased training to 90 days within a 38-week programme offered the potential that student teachers could learn about and practice teaching the arts during their time in schools. However, surveys of primary pre-service teachers in England (Green \& Chedzoy, 1998; Barnes, 2001) found few opportunities for respondents to either observe or teach the arts in primary schools, noting that opportunities were particularly limited in the areas of dance and drama. This may be linked to schools' increased focus upon what the UK government described as 'the basics' of literacy and numeracy; prescribed in national strategies (DfEE, 1998, 1999); inspected and publicly reported upon; assessed centrally and used as the basis for ranking schools in league tables.

Although student teachers in the studies above have reported a lack of opportunity to participate in the arts during their school practices, there have been a number of national initiatives in the past decade have sought to reinvigorate this area of the curriculum in English primary schools. Arguably the first of these was the influential All Our Futures report (NACCCE 1999), championing creative and cultural education. Whilst definitions of the problematic terms 'creativity' and 'culture' were framed in broad, cross-curricular terms, this report can be regarded as a lobby for the arts, which it argued can contribute significantly to a notion of children's creative and cultural entitlement. The report's recommendations were picked up in a number of UK government initiatives, including the incorporation of Creative Development - to include art, music, movement and dance activities - as one of six areas of learning within the early years curriculum (QCA/DfEE 2000); an emphasis on flexibility in teachers' cross-curricular planning in the Excellence and Enjoyment strategy (DfES 2004) and the establishment of a national Creative Partnerships programme in 2005. Creative Partnerships, involving schools working in most cases with arts professionals, illustrates the general characteristic of the above initiatives to equate notions of creativity principally with participation in the arts (Sharp et al., 2006).

This stands in contrast to other educational definitions of creativity, as for example 'imaginativeness or ingenuity manifested in any valued pursuit' (Elliot, 1975); a process leading to 'cultural production' (Sefton-Green and Sinker, 2000), 'a function of intelligence' (Robinson, 2001), or 'going beyond the conventional agreed' (Craft 2000), all of which refer to a domain-independent attribute or activity. Koestler (1964) has defined creativity as 'the ability to make connections between previously unconnected ideas', which suggests that activities which bring different disciplines or curriculum areas together are likely to yield creative opportunities, whilst Craft (2005) refers to 'life-wide' 
creativity which brings together the imaginative acts of an individual across a range of domains. Craft (2008) also points to the importance of collaborative activity in fostering middle c' creativity, lying between the 'Big C' creativity of genius and the 'little c' creativity in which originality is unique to the individual. She suggests that activities which seek to develop partnership between educators and those beyond the classroom may nurture such co-production of possibilities" (p. 243). Such initiatives have become an established part of arts education practice through artist-in-residence schemes (Reiss and Pringle, 2003), Creative Partnerships (see above) and initiatives such as 'Third Space' (Stevenson and Deasy, 2005) which provides evidence of how teachers, artists, and communities can use strategies found in arts instruction to improve their schools. As with notions of creativity in education, similarly 'culture' - defined broadly in All our Futures as 'the shared values and patterns of behaviour that characterise different social groups and communities' (NACCE, 1999, p. 47) has tended to be interpreted in subsequent curriculum initiatives as primarily associated with the arts, exemplified by Find your talent (DCSF/DCMS/Arts Council, 2008) which sets out a 'cultural offer' of 'five hours a week of high quality arts and culture for every child.' Arts educators (e.g. Swift and Steers 1999) have been instrumental in promoting the role of arts integration within cultural education, though it has been acknowledged (Craft, 2005; Troman et al., 2007; Van Eman et al., 2008) that this can create tensions and dilemmas for schools working within a system geared towards performativity and high-stakes testing. Using a circus metaphor, Van Eman et al. (2008, p. 24) relate schools' responses towards arts integration to the types of self-regulation practised by teachers, characterising the teacher who 'flies the trapeze' as one who “... seeks creative solutions to meet school district expectations and teaches in a manner that her experience and thoughtfulness has proven to be best practice in which arts integration transforms student learning." The HEARTS initiative, by giving beginning teachers confidence in participation in the arts and demonstrating the benefits of arts integration, seeks to prepare them to 'fly the trapeze' in their future careers.

Alongside the government-backed reforms to the primary school curriculum described above, there have been some shifts in the legislation governing teacher education, for example the inclusion of a requirement to include 'performing arts' in training curricula (TTA, 2002). However, our previous research in this area (Author et al., 2004) has suggested that primary student teachers lack confidence in their own creativity and that primary headteachers may consider new teachers to lack the flexibility required to plan or a more cross-curricular approach to include the arts. Respondents suggested that more experienced colleagues, who may have started their careers before the introduction of a national curriculum, felt more confident to include the arts within what they perceived as cross-curricular 'topic work', whilst new teachers were fearful of stepping outside prescribed frameworks. Bore (2006) suggested that it was exposure to school culture, with its high levels of accountability through inspection, testing and league tables, which appeared to inhibit student teachers' ability to plan imaginatively. This fearfulness on the part of beginning teachers, together with the tendency for training providers to continue to focus on preparation for teaching numeracy and literacy through fear of being found 'noncompliant' by inspection (OfSTED, 2005), has arguably left a generation of new primary teachers ill-equipped to teach the Arts or combine them innovatively. Swift and 
Steers (1999, p. 12) have argued for a redesigning of the preparation and development of teachers in the arts, "....in order to give them the confidence and ability to embody and promote risk-taking, personal enquiry and creative action and though both before and during their teaching career." It is towards this goal that the HEARTS project has sought to move, by providing funding for HEIs to re-invigorate the Arts components of their programmes. This requires a model of teacher education in which beginning teachers are immersed in an integrated arts experience, working as apprentices alongside more experienced educators and artists, towards becoming a 'creative planner, effective practitioner, and critical thinker' (Scanell 1999, p. 6).

\section{The HEARTS project in action: a case study}

The project upon which this article is based took place in a small university in the West of England, offering a one-year full-time PGCE programme in primary (ages 5-11) and early years education (ages 3-7) to 210 student teachers annually, together with a parttime route over 20 months for 30 teachers preparing for work in early years settings. The programme as a whole has a curriculum focus upon literacy, numeracy and science, striving to maintain a 'reflective practitioner' approach (Schon, 1983) within the standards-based framework of teacher education in England (TTA, 2002; TDA, 2007). The project was based upon a performing arts week, originally introduced into the programme during 2002-3 in response to a perceived deficit in the training curriculum (Rogers, 2003). The week initially involved student teachers participating in dance, drama and music workshops around a theme introduced in a story-telling performance. Groups of student teachers then worked with university tutors to re-tell one of the stories by combining the art forms in different ways as a performance to their peers. Whilst this immersion in arts experience at their own level gave the participants a degree of confidence in their own skills and some ideas to take into their school practice, it did not engage them as 'creative planners, effective practitioners, and critical thinkers' (Scannell, 1999). With HEARTS funding, we were able to expand the scope of the performing arts week to involve local 'cultural centres' (a children's theatre and nine museums) and eight primary schools, to provide a collaborative experience in working with outside professionals (Stevenson and Deasy, 2005; Craft, 2008) and planning for arts integration in the classroom. Aims for the student teacher participants during the week were as follows:

1. to gain confidence, ideas and strategies for teaching art, dance, music and drama in primary schools;

2. to take part in a range of creative and challenge-type activities, both as individuals and as part of a group;

3. to appreciate some of the learning opportunities offered by working in alliance with local schools and cultural centres such as theatres and museums;

4. to know and understand what it is possible to achieve in a range of art forms when working with children;

5. to work towards improving knowledge, skills and understanding in the various arts forms, celebrating experiences through a range of activities including performances;

6. to engage in the key performing arts elements of composition, performance and appreciation/evaluation in the context of the primary classroom. 
Museum educators provided two-hour workshops in the use of objects from their collections as starting points for arts-based activities, encouraging the student teachers to use objects to tell stories from the different cultural and historical perspectives of those who had owned or worn the objects (e.g. a 19th Century coal miner in the local industrial museum, a Japanese Geisha in the Museum of East Asian Art). Theatre educators worked with university tutors to offer workshops in different arts disciplines - music, dance, drama and visual arts - culminating in a cross-disciplinary performance in the theatre coordinated by a professional director. This performance was based upon the idea of a 'living museum' in which participants in the dance, drama, music and visual arts workshops became interactive museum exhibits and the 'audience' took on the role of museum visitors. The curriculum perspective adopted was one of specialisation and collaboration: student teachers were invited to select an art form in which they already had some experience, then combine with others from different art form workshops to explore the creative possibilities offered by integrating their specialisms within a single performance. The second half of the week involved the student teachers in planning collaboratively in these cross-disciplinary teams to interpret the model of arts integration they had experienced in the context of local primary schools and early years settings. For the school-based element, the student teachers worked in groups of around 20 in apprenticeship alongside an arts specialist tutor to develop a 'living museum' performance using the techniques and strategies they had earlier experienced. They initially worked with children in arts specialism workshops, later bringing them together in cross-disciplinary groups to combine their arts experience and ideas into miniperformances which they presented to each other and discussed. At the end of the week, tutors invited student teacher participants to reflect critically upon their own and the children's 'creative learning' (Craft, 2005) through the experience.

\section{Research design}

The project described above was subject to external evaluation by the National Foundation for Educational Research (NFER) working on behalf of the funders, and also to internal evaluation by a team of three university researchers who observed all elements of the week and conducted a range of informal interviews (see below). The internal evaluation adopted a multi-method approach (Saxe and Fine, 1979; Patton, 1990; Bennet, 2003), gathering a range of qualitative and quantitative data to provide triangulation in seeking to address the following research questions (unless otherwise specified, 'participants' here refers to the student teachers participating in the week):

1. To what extent has the project supported student teachers' confidence in participation in the Arts?

2. To what extent has the project developed participants' understanding of the value of the arts in primary education?

3. To what extent has the project developed participants' understanding of the relationships between the arts, creativity and cultural education?

4. To what extent have participants been enabled to participate in a network of adults, taking on different roles within cultural and educational settings? 
5. To what extent have participants come to value a multidisciplinary approach across art forms?

6. To what extent has the project developed participants' confidence to teach the arts in schools?

The first phase of data collection was undertaken in October 2007, at the beginning of the PGCE programme. It consisted of a participant student survey, involving Likert-type attitude scales with optional written commentary $(n=189$, see appendix A). Researchers also attended each of the planning meetings between university tutors, museum and theatre educators, collecting minutes of these meetings and planning documentation.The main phase of data collection took place during the performing arts week itself, in February 2008. This consisted of observations of participants during museum visits, arts workshops and theatre performance, together with observations of participants involved in collaborative planning for the school-based element of the week and whilst they were working with groups of children in the schools. Observations were recorded using field notes, digital photographs and digital video. Researchers also conducted audio-recorded interviews with participant students in small groups ( $\mathrm{n}=37$ groups), university tutors and museum educators $(n=10)$ and teachers in participating schools $(n=11)$ during the week. See appendix B for interview schedules.

Following the performing arts week participants were again invited to complete the above survey $(n=189)$, enabling direct comparisons to be made with individuals' answers at the beginning of the programme. During the subsequent final block school experience (April to June 2008) supervising tutors were asked to identify examples of crossdisciplinary arts projects being undertaken by participant students. The final phase of data collection consisted of email communication with participants during the first term of their new posts (October to November 2008), inviting them to report examples of their arts teaching at the start of their careers. Triangulation between the various data sources was used as follows: interviews with student teachers were used to validate survey data and probe issues in greater depth. Observations of participants in the theatre, museums and schools during the week were used to provide context for their verbal comments. Interviews with museum educators, tutors and teachers were used to provide different perspectives on the student teacher experience and learning through comparison with their interview data. Other data collected during subsequent months from tutors and student teachers were not triangulated as they referred in each case to different individuals' work in schools.

\section{Results}

The findings below have been grouped under headings drawn from the research questions in section 3 above. Data presented are largely drawn from the repeated survey and student teacher interviews (except for section 4.6 below), having been triangulated with other data sources as described above. As previously, unless otherwise specified, 'participants' here refers to the student teachers participating in the week.

\subsection{Participant students teachers' confidence in participation in the arts}


Responding to a definition of the arts as comprising the disciplines of dance, drama, music and visual arts - as identified by primary teachers in Downing's study (2003) - a majority of respondents to the initial survey $(63 \%)$ felt that the arts had been an important part of their own education, whilst $37 \%$ claimed to still participate in the arts as adults. $49 \%$ regarded themselves as 'artistic' in the initial survey, rising to $59 \%$ following the performing arts week, with only $17 \%$ disagreeing with the statement 'I consider myself to be artistic'. Tutors of arts workshops interviewed during the week reported a willingness to participate and relatively high levels of participant confidence, whilst student teacher interviews reflect some initial uncertainty - "being outside your comfort zone" - with a general growth in confidence as the week progressed.

\subsection{Participant student teachers' appreciation of the value of arts education}

In response to the initial survey, $37 \%$ agreed that the arts should be at the centre of the curriculum, whilst this figure rose to $45 \%$ following the performing arts week. $93 \%$ agreed that 'participation in the arts is fundamental to children's learning' at the outset of their programme, citing the development of skills, knowledge, emotional intelligence and self esteem as key learning outcomes. The numbers strongly agreeing with this statement rose from $38 \%$ to $47 \%$ in the second survey. Asked in interviews why they felt that an arts education was important, several pointed to the habit-forming influence of exposure to experiences children may not be able to access from home. Participants' experience during the project, compared with their observations in primary schools during their previous teaching placement, led them to be increasingly critical of the position of the arts in the taught curriculum, with an increase from $12 \%$ to $24 \%$ of students agreeing strongly that 'most primary schools fail to devote sufficient time to the arts.' The importance attached to the arts in the primary curriculum by participants was reflected in interview data and their subsequent reports of work undertaken during the early weeks of their teaching careers.

\subsection{Participant student teachers' understanding of the relationship between the arts, creativity and cultural education}

In the initial survey, $37 \%$ of respondents agreed with the statement that 'creativity is mainly associated with the arts.' During the performing arts week, interviewees agreed that the various experiences and activities had allowed them to use their creativity, however the proportion agreeing with this statement dropped to $29 \%$ after the week. When asked to define cultural education, three distinct strands could be identified in participants' responses. The first of these we might term a multicultural definition, concerned with living in a plural society and developing children's respect for each other:

"It's the central aspect of today's teaching isn't it because our community is so multicultural. You have to have the knowledge and the respect for all the different cultures for the children that you might have." (student teacher, day 1) 
Related to this, culture was seen as something other; a transformative experience taking children out of their everyday experience:

"Something out of your normal, to experience or to try and create an understanding of something you've not encountered before and to perhaps broaden your own opinion or perhaps to broaden your mind about how other people live or work..." (student teacher, day 2)

The second strand might be termed an historical definition, although it also incorporated elements of a multicultural perspective:

"I think looking at art, music or history of other cultures so whether it be African, American Indians, Japanese. Just looking at different countries or even British, I suppose, Victorians or Georgians, the way that things were done." (student teacher, day 2)

Museums were seen as important in helping children to make links between their own experience and the cultures of the past:

"The fashion museum was quite interesting because you could immediately see how you could really engage them in terms of their clothing and what they consider fashionable now...." (student teacher, day 2)

The third strand in students' definition of culture could be termed an artistic strand, in which they recognised the role of the arts in enriching cultural life. $86 \%$ agreed with the statement 'the arts are fundamental to children's cultural development' in the initial questionnaire, whilst the number strongly agreeing with this statement rose from $27 \%$ to $37 \%$ following the project. However, interviewees struggled to make links between their museums experience and the arts workshops in the egg. The most difficult aspect of the week for many was using cultural objects as stimuli for arts activities:

"I think if we had been doing (art) in a traditional sense - creating a picture or sculpture or something - I think that would have been very easy just to pick something that we've seen, something that we enjoyed to see, and draw on it or created a sculpture from it. But in terms of trying to create a piece of music from something we saw yesterday I can't, I don't know how to do that." (student teacher, day 2)

When questioned whilst they were undertaking activities in schools, many did not relate the museums experience to their work in the arts, despite finding it valuable in its own right. This however was not a universal response. Some felt that they had been able to make effective thematic links, particularly where the school had already been working with a museum or gallery collection.

\subsection{Participant student teachers' abilities to take on different roles in a network of adults}


Participants already had some awareness at the beginning of the programme of the value of arts professionals working alongside teachers in primary schools; this appreciation of the role of the artist in education increased from $67 \%$ to $75 \%$ by the end of the project. In terms of negotiating their own role in a team of their peers, tutors, teachers and artists, participants reported needing to make a rapid adjustment from the 'class teacher' role (solely responsible for teaching the whole curriculum to a specified class of children) they had been expected to take on during their school placement which immediately preceded the week. Following the joint planning day in the middle of the week, several students were still anxious about working in a team within an unknown school. However, the new situations in which they found themselves brought out latent leadership potential, as observed by tutors:

"Directing and leading from students I wouldn't have ever thought would direct and lead. Particularly ones I know well from school experience and my own tutor group.

I've seen them taking on that kind of role." (music tutor, day 3 )

Once they got into the schools, some groups found it difficult adapting to a team-teaching situation, which they related to unfamiliarity with each others' teaching styles. However, others felt that the team situation was supportive in the 'risky' situation in which they found themselves. One of the outcomes of group support in the school settings was the opportunity for students to allow children to take on more responsibility for the decisions within the project. This commitment to an open-ended style of working with the children was noticed and appreciated by the staff in the schools:

"I can see that they clearly planned what they're going to do but they don't know exactly where it's going to go because they're actually including the children in the decisions in what they're going to do." (teacher, day 5)

Students were observed taking on the roles of participant, planner, artist, teacher, group member and co-professional alongside their more experienced teaching colleagues.

\subsection{Participant student teachers' attitudes towards a multidisciplinary approach across art forms}

At the beginning of their programme, most participants were unsure of the value to children's learning of combining different art forms, however by the end of the performing arts week they gave a more positive response to the corresponding statement within the survey (51\% agreeing by comparison with $33 \%$ beforehand). When interviewed, student teacher participants identified the director's workshop in the children's theatre - in which the individual arts workshops had been combined into a 'living museum' - as having been significant in helping them to see the links between the art forms. Participating in the 'living museum' performance was perceived as providing a structure within which they could work when taking the model into schools. Their examples of subsequent arts education practice exemplified the value many placed on cross-disciplinary work (see 4.7 below). 


\subsection{Participant student teachers' confidence in teaching the arts}

Following the project, $86 \%$ of survey respondents agreed with the statement 'I feel confident to include the arts in my own teaching', whilst $58 \%$ expressed confidence that they could bring together different art forms in their teaching. Interviewees suggested that the performing arts week had developed their confidence by modelling a range of ideas and approaches:

"... watching it all being put together gave me lots of ideas about how to incorporate drama into everyday situations in the classroom." (student, day 3 )

School staff also commented on the student teachers' ideas for teaching the arts, which could potentially inform school practice:

"... a lot of the things they did were different to what we had been doing at the start of the week, it was a fresh way to look at it. I think part of that's down to the University with the workshops they do with the students for us. We kind think, oh I can do that with my own class." (teacher, day 5).

The following list provides examples of arts projects initiated by participating student teachers in primary schools since the project:

- a project on the theme of 'sundials', incorporating science, mathematics, sculpture and dance;

- using the starting point of a bicycle as a stimulus for creative and explanatory writing, dance, design \& technology and art;

- a topic on archaeology which involved making up stories about archaeological finds and putting them into a familiar tale setting;

- felting, printing and creative writing based on a Van Gogh painting of a wheat field. The class used the picture to generate interesting research questions and linked it to their poetry unit (a poem on harvest);

- using the idea of a working museum exhibit for mixed age-group children to give presentations on one of Brunel's inventions;

- making Tudor costumes out of fabric and beads for children to experience what they would have looked like as a Tudor;

- making sock puppets of the characters in The Lighthouse Keeper's Lunch and using these for role play, hot seating and eventually to make a silent movie of the story with the children doing the voices and sound effects over the top;

- using role-play, character hot-seating and freeze frames for looking at the beginning, middle and ends of stories in literacy;

- using musical instruments to explore poetry, trying to relate the sounds to the words in the poems.

In many cases, participants' reported that such examples of their subsequent practice had drawn directly upon the techniques explored during the performing arts week. 


\section{Discussion}

The degree of confidence in participation in the arts expressed by the participants in this programme contrasts with the student teacher attitudes reported by one of the first cohort of ITE providers involved in HEARTS (Barnes and Shirley, 2007, p. 173). However, there appears to have been a difference in confidence levels between the first and second HEARTS cohorts:

“... perhaps the most pronounced difference was the degree of initial apprehension surrounding the three earlier HEARTS projects compared to those in the later ones. Fewer students in the later group resisted involvement as those before had done." (Downing et al., 2007, p. 34)

Confidence levels in the participants in this study appear to have continued this trend, which whilst welcome is difficult to explain in terms of changes in the arts education successive groups of student teachers may have experienced themselves. It possibly reflects participants' perceptions of an enhanced role for the arts in the primary schools they had been required to visit before starting the programme, resulting from the shifts in government policy referred to in section 1 above, for example the greater curricular freedom promoted by Excellence and Enjoyment (DfES 2004). However, even if their confidence levels had higher starting points than previous HEARTS groups, their growth through the project reflects findings from previous studies which reported enhanced enjoyment, self esteem and confidence in participating in the arts (Downing et al., 2007). Similarly, the shifts in attitude towards the value of arts education in the primary curriculum reported in section 4.2 are supported by findings from earlier projects (ibid.), which pointed to the importance of working directly with children in an arts project of this nature, in order to observe the effects of participation on children's learning and self esteem.

Much of the professional literature on creativity in primary education links children's creative development to participation in the arts in some form (e.g. Craft, 2003, Wilson, 2005, Bancroft et al., 2008), a theme reflected in government documentation as reported in section 1 above. Our own work in this area (Author et al., 2004) found that student teachers selected art lessons as those most likely to offer scope for creativity, reflecting the close links - and possibly confusion - between the terms 'art' and 'creativity' in their minds. The finding, reported in section 4.3 above, that $37 \%$ saw creativity as 'mainly associated' with the arts in the initial survey, is less pronounced than the responses in our earlier study (ibid.) but still suggests a significant association in participants' minds. That this figure dropped slightly following the performing arts week, despite many interviewees reporting that they had used their creativity during the week, reflects perhaps a broadened and more developed understanding of the term 'creativity' as applying across the curriculum. This broadening of their view of creativity was also observed in previous HEARTS projects (Downing et al., 2007). By contrast, the identification between participation in the arts and children's cultural education was strengthened during the week, reflecting perhaps the messages participants had received 
through the incorporation of museum workshops, despite the difficulties some found in using museum artefacts as starting points for arts performance. The reasons for this mixed response could be twofold. Possibly the breadth of types of museum represented in the project - necessitating a very broad overarching theme - made it more difficult for participants to make obvious thematic links, a point made by one of the arts tutors and echoed by one of the headteachers of the schools involved. Another factor could have been the variable quality of the museum education input, as reported by interviewed participants. By contrast, the museum educators interviewed greatly valued the opportunity to work with student teachers and to 'open their eyes' to the educational potential within what the educators regarded as important local cultural centres. The range of participants' definitions of 'cultural education' referred to in section 4.3 above raises the possibility that there was a lack of shared understanding of this contested term between museum educators and student teachers. Developing working definitions of such terms between the various groups involved in such a project (university tutors, artists, museum educators) would possibly have helped to clarify the conceptual field for participants.

However, official documentation on cultural education (e.g. DCSF/DCMS/Arts Council, 2008) generally fails to make such definitions explicit, assuming shared understandings which may not exist. This anxiety expressed by participants in taking on different roles within the school-based element of the project (section 4.4 above) is reflected in findings from previous HEARTS projects, in which it was related to a reluctance to take on the levels of responsibility required (Barnes and Shirley, 2007). Given that the student teachers in this study had taken on a whole-class teaching role for the previous five weeks, a reluctance to take responsibility seems unlikely. Rather, the ability to 'step back' into a less prominent role within a collaborative group of adults appeared to present challenges to some. Within the 'remodelling' of the children's workforce anticipated by the UK government's social inclusion strategy Every Child Matters (DfES 2004), teachers are increasingly expected to take on a variety of roles within a multi-disciplinary team of professionals. Although few interviewees reported having observed this teamwork in action during their previous school experiences, the experience of working collaboratively with peers, arts tutors and teachers should have begun to prepare them for their changing future roles. That some found it difficult to step out of 'class teacher' mode is perhaps indicative of the difficulties faced more widely in moving towards a 'remodelled' workforce.

The greater appreciation of the value of a multi-disciplinary approach in the arts, reported in section 4.5 above, is reflected in findings from a previous study (Barnes and Shirley, 2007). However, in the latter project the student teacher participants reported that the apparent ease with which the tutors made cross-curricular links between art forms was difficult to replicate, as their limited experience and unfamiliarity with cross-curricular working made the links harder to see. This reflects the findings from our earlier study (Author et al., 2004), suggesting that headteachers perceived beginning teachers as struggling to innovate in the curriculum by comparison with their more experienced colleagues who had a background in cross-curricular 'topic work'. An apparent government sanctioning of a return to topic work (DfES 2004) has arguably 
disadvantaged newer teachers, given that the majority of primary teacher education courses have remained 'subject bound' in recent years (Rogers, 2003). However, this does not appear to have emerged in our findings, perhaps because the participants in our study had observed more examples of cross-curricular work during school experience than previous groups, upon which they could draw during the performing arts week. They exhibited confidence in teaching across the art forms during the school-based days, and in some cases subsequently during block school experience, as reported in section 4.6 above.

In their overview study of the first six HEARTS projects, Downing et al. (2007, p. 35) noted a shift from the first to the second cohort towards: "projects which were more directly oriented towards practice and the development of new teaching ideas and better understanding of how to teach the arts in the primary curriculum." The inclusion of a school-based, student teacher-led component in the project reported on here continues this trend. This appears to have supported participants' growth in confidence to teach the arts in school, a finding supported by examples from previous projects with a schoolbased element (Downing et al., 2007). Donahue and Stuart (2006, pp. 351-2) have characterised new teachers' orientations to arts integration in their practice as 'making', 'analysing' or 'balancing', the last of which they identify as "... more likely than the other two approaches to make connections between the arts and other disciplines explicit...". Of the examples of subsequent arts teaching cited in section 4.6, it could be argued that the 'sundials' and 'bicycle' projects involved the kinds of two-way interaction between the arts and other disciplines characteristic of Donahue and Stuart's 'balancing' orientation, whilst others were more focused on 'making'. The emphasis on 'making' may reflect a perceived emphasis within the performing arts week, or is perhaps influenced by predominant practice in the schools in which participants subsequently found themselves. An increased emphasis upon the museums element of the project could have led to a more even balance between the making and performing elements of arts practice and its contribution to broader conceptions of cultural education involving areas of the curriculum such as history and technology. This may then have been reflected in participants' subsequent practice.

\section{Conclusions}

The project evaluated above has extended a pre-existing performing arts week within a one-year primary ITE programme to develop an innovative partnership between museums, theatre, schools and the university. There is evidence that this partnership has provided an experience for student teachers which has strengthened their self-image as artistic individuals who recognise the value of the arts in children's education and have enhanced confidence in working with different professionals to teach the arts in a crossdisciplinary way. Although the integration of the museums element has tended to dilute the thematic focus of the week - making it difficult for some students to perceive the links between the different elements - it seems to have strengthened their understanding of cultural education and their abilities to use objects in their teaching of the arts. The museums element has also arguably helped participants make links between the arts and other areas of the curriculum such as history. A more sharply-defined theme with a 
smaller number of museums in future years could give greater coherence to the whole experience. This kind of project within the tight confines of a one year PGCE programme demands a high level of organisation and commitment amongst staff, and certainly benefits from external funding. To an extent, any 'one week' event is open to accusations of 'tokenism'. Nevertheless, if the model builds upon other arts input through the programme - in the above case ongoing music, art, drama and dance workshops - and also spreads out into other programme elements - such as school experience - it represents a significant enrichment of an otherwise closely regulated training curriculum (TDA, 2007). Participants in this project have needed to negotiate a number of intersecting layers of accountability - their own requirement to meet a set of professional standards, the training provider's need for compliance with government requirements, and the schools' accountability for pupil attainment in non-arts subjects as measured through national testing and inspection. The penalties for perceived failure within any of these layers of accountability are extreme - failure to qualify as a teacher, withdrawal of accreditation as a training provider, or potential closure as a school. The threat of such sanctions has arguably bred a culture of fear within the teaching profession which has particularly affected pre-service teachers' confidence to innovate (Author et al., 2004), whilst being aware that they are expected to do so by subsequent government initiatives in creative and cultural education (DfES, 2004, DCSF/DCMS/Arts Council, 2008). Understanding this tension in their professional lives and overcoming their fear of introducing cross-curricular arts practice in their classrooms will remain a continuing challenge for new primary teachers in England. 


\section{Appendix A: HEARTS project 2007-8 Participant Survey}

We are part of the national HEARTS project (Higher Education, the Arts and Schools: an experiment in educating teachers). This questionnaire aims to find out about your experiences and ideas about the arts in schools (music, dance, drama, art \& design) at the beginning of the project.

\begin{tabular}{l|l|l|}
\hline Your name: & Teaching group:
\end{tabular}

For each question below, please indicate the extent to which you agree or disagree with the statement, using the scale provided. Then use the space after each question to explain the reason for your answer.

\begin{tabular}{|c|c|c|c|c|c|}
\hline $\begin{array}{l}\text { The arts were a very } \\
\text { important part of my } \\
\text { own education }\end{array}$ & $\begin{array}{l}\text { STRONGLY } \\
\text { DISAGREE } \\
\text { (1) }\end{array}$ & $\begin{array}{l}\text { DISAGREE } \\
\text { (2) }\end{array}$ & $\begin{array}{l}\text { NEUTRAL } \\
\text { (3) }\end{array}$ & $\begin{array}{l}\text { AGREE } \\
\text { (4) }\end{array}$ & $\begin{array}{l}\text { STRONGLY } \\
\text { AGREE } \\
\text { (5) }\end{array}$ \\
\hline
\end{tabular}

Please explain your reasons for your score

2 I regularly participate in the arts as an adult
STRONGLY DISAGREE (1)
DISAGREE

(2)
NEUTRAL (3)
STRONGLY

AGREE

Please explain your reasons for your score (which arts do you participate in?)

\begin{tabular}{|c|c|c|c|c|c|}
\hline $\begin{array}{l}\text { I consider myself to be } \\
\text { artistic }\end{array}$ & $\begin{array}{c}\text { STRONGLY } \\
\text { DISAGREE } \\
\text { (1) }\end{array}$ & $\begin{array}{c}\text { DISAGREE } \\
\text { (2) }\end{array}$ & $\begin{array}{l}\text { NEUTRAL } \\
\text { (3) }\end{array}$ & $\begin{array}{l}\text { AGREE } \\
\text { (4) }\end{array}$ & $\begin{array}{c}\text { STRONGLY } \\
\text { AGREE } \\
\text { (5) }\end{array}$ \\
\hline
\end{tabular}

\begin{tabular}{|c|c|c|c|c|c|}
\hline $\begin{array}{l}\text { Creativity is mainly } \\
\text { associated with the arts }\end{array}$ & $\begin{array}{c}\text { STRONGLY } \\
\text { DISAGREE } \\
\text { (1) }\end{array}$ & $\begin{array}{c}\text { DISAGREE } \\
\text { (2) }\end{array}$ & $\begin{array}{c}\text { NEUTRAL } \\
\text { (3) }\end{array}$ & $\begin{array}{l}\text { AGREE } \\
\text { (4) }\end{array}$ & $\begin{array}{c}\text { STRONGLY } \\
\text { AGREE } \\
\text { (5) }\end{array}$ \\
\hline
\end{tabular}

5 Every child should have an entitlement to an arts education

\section{STRONGLY DISAGREE} (1)
DISAGREE (2)
NEUTRAL (3)
STRONGLY

AGREE (5)

Please explain your reasons for your score

6 The arts are fundamental to children's learning

\section{STRONGLY DISAGREE}

DISAGREE

(2)

NEUTRAL (3)
AGREE

(4)

GREE (4)

Please explain your reasons for your score
7

The arts are
fundamental to
children's cultural
development

STRONGLY DISAGREE

DISAGREE (2)

(3)

(3)

(

AGREE

STRONGLY

AGREE

(4) (5)

Please explain your reasons for your score

\begin{tabular}{|l|l|l|l|l|l|}
\hline 8 & $\begin{array}{l}\text { When the arts are } \\
\text { taught together they are } \\
\text { more powerful than } \\
\text { when taught separately }\end{array}$ & $\begin{array}{c}\text { STRONGLY } \\
\text { DISAGREE }\end{array}$ & $\begin{array}{c}\text { DISAGREE } \\
\text { (1) }\end{array}$ & $\begin{array}{c}\text { NEUTRAL } \\
\text { (3) }\end{array}$ & $\begin{array}{c}\text { STRENGLY } \\
\text { AGREE } \\
\text { (3) }\end{array}$ \\
\hline
\end{tabular}


(1)

The arts should be at the centre of the primary curriculum

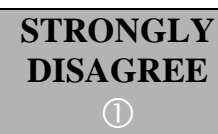

(1)

DISAGREE

NEUTRAL

AGREE

STRONGLY

(2)

(3)

(4)

AGREE

(5)

Please explain your reasons for your score

$10 \begin{aligned} & \text { In my experience, most } \\ & \text { primary schools don't } \\ & \text { devote enough time to } \\ & \text { the arts }\end{aligned}$

STRONGLY
DISAGREE
(1)

DISAGREE

NEUTRAL

AGREE

STRONGLY

AGREE

Please explain your reasons for your score

In my experience,
school timetables tend
to be too rigid to
develop children's
creativity

STRONGLY
DISAGREE
(1)
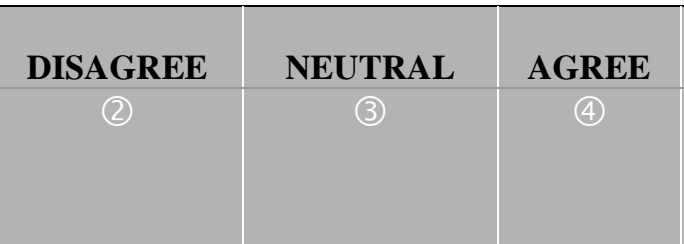

STRONGLY

Please explain your reasons for your score

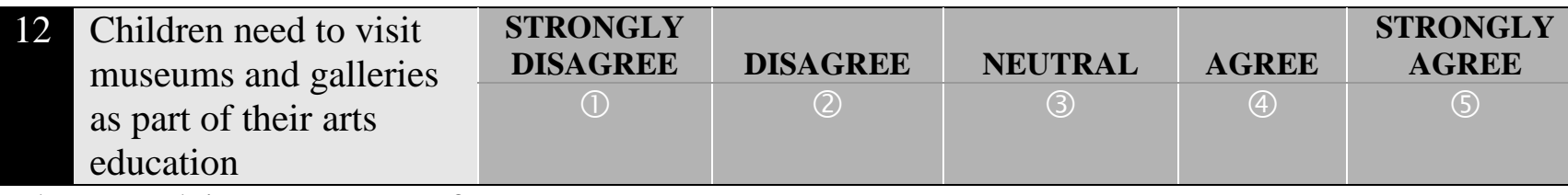

Please explain your reasons for your score

\begin{tabular}{|c|c|c|c|c|c|c|}
\hline 13 & $\begin{array}{l}\text { I have experience of } \\
\text { teaching the arts in }\end{array}$ & $\begin{array}{l}\text { STRONGLY } \\
\text { DISAGREE }\end{array}$ & DISAGREE & NEUTRAL & AGREE & $\begin{array}{c}\text { STRONGLY } \\
\text { AGREE }\end{array}$ \\
\hline & primary schools & (1) & (2) & (3) & (4) & (5) \\
\hline
\end{tabular}

\begin{tabular}{l|l|c|c|c|c|c|}
\hline 14 & $\begin{array}{l}\text { I have experience of } \\
\text { working with artists } \\
\text { (dancers, musicians }\end{array}$ & $\begin{array}{c}\text { STRONGLY } \\
\text { DISAGREE }\end{array}$ & DISAGREE & NEUTRAL & AGREE & $\begin{array}{c}\text { STRONGLY } \\
\text { AGREE }\end{array}$ \\
etc.) in primary schools & & (1) & (3) & (4) & (5) \\
\hline
\end{tabular}

Please explain your reasons for your score

\begin{tabular}{l|l|c|c|c|c|c|}
15 & $\begin{array}{l}\text { Children need to work } \\
\text { with artists in primary } \\
\text { schools }\end{array}$ & $\begin{array}{c}\text { STRONGLY } \\
\text { DISAGREE }\end{array}$ & DISAGREE & NEUTRAL & AGREE & $\begin{array}{c}\text { STRONGLY } \\
\text { AGREE }\end{array}$ \\
\hline
\end{tabular}

Please explain your reasons for your score

\begin{tabular}{|c|c|c|c|c|c|}
\hline $\begin{array}{l}16 \text { I feel confident to } \\
\text { include the arts in my } \\
\text { own teaching }\end{array}$ & $\begin{array}{c}\text { STRONGLY } \\
\text { DISAGREE } \\
\text { (1) }\end{array}$ & $\begin{array}{l}\text { DISAGREE } \\
\text { (2) }\end{array}$ & $\begin{array}{l}\text { NEUTRAL } \\
\text { (3) }\end{array}$ & $\begin{array}{c}\text { AGREE } \\
\text { (4) }\end{array}$ & $\begin{array}{c}\text { STRONGLY } \\
\text { AGREE } \\
\text { (5) }\end{array}$ \\
\hline
\end{tabular}

Please explain your reasons for your score

\begin{tabular}{|c|c|c|c|c|c|}
\hline $\begin{array}{l}17 \text { I know how to bring } \\
\text { together different art } \\
\text { forms in my teaching }\end{array}$ & $\begin{array}{l}\text { STRONGLY } \\
\text { DISAGREE } \\
\text { (1) }\end{array}$ & $\begin{array}{l}\text { DISAGREE } \\
\text { (2) }\end{array}$ & $\begin{array}{c}\text { NEUTRAL } \\
\text { (3) }\end{array}$ & $\begin{array}{l}\text { AGREE } \\
\text { (4) }\end{array}$ & $\begin{array}{l}\text { STRONGLY } \\
\text { AGREE } \\
\text { (5) }\end{array}$ \\
\hline
\end{tabular}




\section{Appendix B: Interview schedules}

Questions for students during week (various times)

1. Which experiences today have made the most impact on you? Why?

2. Which art forms do you think you've covered today?

3. What connections can you make between the different art forms?

4. Have you had an opportunity to use/develop your creativity today? If so how?

5. How can you see this working with children?

6. What does cultural education mean to you? What examples of cultural education have you experienced this week?

7. What links have you been able to make between your experiences in the egg and in museums?

8. What different roles have you played this week?

9. What has been your experience of working in a team? Have different members contributed different expertise?

10. Tell me about the planning process for school work? Has this been difficult to negotiate?

11. What have you learnt about children's creativity this week?

12. How have children responded to your input - any particularly creative responses?

13. What have you learnt about teaching the arts this week?

Questions for Museum Educators (Monday, Tuesday)

1. How have the students responded to your workshop today?

2. Have they been able to make the links between the museum input and the performing arts element?

3. How do you see the contribution your museum can make to their development as teachers?

4. What have you got out of being involved?

Questions for the egg staff (Monday, Tuesday)

1. How have the students responded to their day in the egg?

2. What questions have they been asking?

3. What do their performances tell you about their understanding of the performing arts in education?

4. What connections have they been able to make between the different art forms?

5. How do you see your contribution towards students' understanding of the importance of the arts in education?

6. What have you got out of being involved?

Questions for tutors (Wednesday - Friday)

1. How have the students responded to your workshop?

2. What connections have they made between the different art forms?

3. Have they been able to make the links between the museum input and the performing arts element?

4. What has been the 'added value' of the museum element? 
5. What different roles have you seen them taking on in the workshops, in planning sessions, in school?

6. What have you got out of being involved?

Questions for teachers (Thursday - Friday)

1. How well do you feel the students have led the performance workshops in schools?

2. Has anything struck you about the ways in which they have worked with the children?

3. How well do you think they've been able to combine the museum input with the performance element?

4. What connections have they made between the different art forms?

5. How confident are you that these students have a good understanding of the importance of the arts in education?

6. What do you think the children have got out of it?

7. What have you got out of being involved?

\section{Acknowledgements}

The authors acknowledge the financial support of Esmee Fairbairn Trust and Calouste Gulbenkian Foundation, through the HEARTS initiative, for this work.

\section{References}

Author [details removed for peer review], Howe, A., Rogers, M. and Fasciato, M. (2004) How do trainee primary teachers understand creativity? In E. Norman, D. Spendlove, P. Grover \& A. Mitchell (Eds.) Creativity and Innovation - DATA International Research Conference 2004 (pp. 41-54). Wellesbourne: DATA.

Bancroft, S., Fawcett, M. and Hay, P. (2008) Researching Children Researching the World: $5 \times 5 \times 5=$ creativity. Stoke-on-Trent: Trentham Books.

Barnes, J. (2001) Creativity and composition in music. In C. Philpott \& P. Plummeridge (Eds.) Issues in Music Education (pp. 90-110). London: Routledge.

Barnes, J. \& Shirley, I. (2007) Strangely familiar: cross-curricular and creative thinking in teacher education, Improving Schools 10, 162-179.

Bennet, J. (2003) Evaluation Methods in Research. London: Continuum.

Bore, A. (2006) Creativity, Continuity and Context in Teacher Education: Lessons from the Field, Australian Journal of Environmental Education, 22(1), 31-38.

Craft, A. (2000) Creativity Across the Primary Curriculum: Framing and Developing Practice. London: Routledge. 
Craft, A. (2003) Creative Thinking in the Early Years of Education, Early Years 23(2), 143-154.

Donahue, D. \& Stuart, J. (2006) Working towards balance: Arts integration in pre-service teacher education in an era of standardization. Teaching and Teacher Education, 24, 343355.

Downing, D. \& Lamont, E. with Newby, M. (2007). HEARTS Higher Education, the Arts and Schools: an Experiment in Educating Teachers. Slough: NFER.

Department for Children, Schools and Families (DCSF) (2007) The Primary Framework for literacy and mathematics. London: DCSF.

Department for Children, Schools and Families (DCSF)/ Department for Culture, Media and Sport (DCMS)/ Arts Council (2008) Find Your Talent Prospectus. Available online at: http://www.findyourtalent.org/pdf/prospectus.pdf (accessed 20.11.08).

Department for Education and Employment (DfEE) (1998a) Circular 4/98: Requirements for Courses of Initial Teacher Education. London: DfEE.

Department for Education and Employment (DfEE) (1998b) The National Literacy strategy: A Frameworkfor Teaching. London: DfEE.

Department for Education and Employment (DFEE) (1999) The National Numeracy Strategy London: DfEE.

Department for Education and Skills (DfES) (2003) Excellence and Enjoyment - the National Primary Strategy. London: DfES.

Downing, D., Johnson, F. and Kaur, S. (2003). Saving a Place for the Arts? A Survey of the Arts in Primary Schools in England (LGA Research Report 41). Slough: NFER.

Elliot, R. K. (1975) Imagination, a Kind of Magical Faculty, Inaugural lecture, University of Birmingham, 1975..

Green, L. \& Chedzoy, S. (1998) A study of student teachers' perceptions of teaching the arts in primary schools. British Educational Research Journal, 24(1), 95-107.

Koestler, A. (1964). The Act of Creation. London: Hutchinson.

National Advisory Committee on Creative and Cultural Education (NACCCE) (1999) All Our Futures: Creativity, Culture and Education. Suffolk: DfEE.

Office for Standards in Education (OfSTED) (2005) Framework for the inspection of initial teacher training for the award of qualified teacher status 2005-11. (Available online: http://www.ofsted.gov.uk/Ofsted-home/Forms-and-guidance/Browse-all- 
by/Other/General/Framework-for-the-Inspection-of-Initial-Teacher-Training-forinspections-from-September-2005/(language)/eng-GB. Accessed 23.11.08)

Patton, M. (1990) Qualitative Evaluation and Research Methods. (2nd ed.). Newbury Park, CA: Sage.

Qualifications and Curriculum Authority/Department for Education and Employment (2000) Curriculum Guidance for the Foundation Stage. London: DfEE/QCA.

Reiss, V. and Pringle, E. (2003) The Role of Artists in Sites for Learning, International Journal of Art and Design Education 22(2), 215-221.

Robinson, K. (2001) Out of Our Minds: Learning To Be Creative. Oxford: Capstone.

Rogers, R. (1998). The Disappearing Arts? The Current State of Arts in Initial Teacher Training and Professional Development. London: Royal Society for the Encouragement of Arts, Manufactures and Commerce (RSA).

Rogers, R. (2003). Time for the Arts? The Arts in the Initial Training of Primary School Teachers: A Survey of Training Providers in England. Wednesbury: Wednesbury Education Action Zone.

Saxe, L. \& Fine, M. (1979) Expanding our view of control groups in evaluations. In L. E. Datta \& R. Perloff (eds.) Improving Evaluations. Beverley Hills, Calif.: Sage.

Scannell, D. P. (1999) Models of Teacher Education: Report to the American Council on Education Presidents' Task Force on Teacher Education. (Available online: http://curie.umd.umich.edu/TeacherPrep/74.pdf . Accessed 31.3.09).

Schon, D. (1983) The Reflective Practitioner. New York: Basic Books.

Sefton-Green, J. and Sinker, R. (2000) Evaluating Creativity: Making and Learning by Young People. London: Routledge.

Sharp, C., Pye, D., Blackmore, J., Brown, E., Eames, A., Easton, C., Filmer-Sankey, C., Tabary, A., Whitby, K., Wilson, R. \& Benton, T. (2006). National Evaluation of Creative Partnerships. Final Report. London: Creative Partnerships.

Teacher Training Agency (TTA)/Office for Standards in Education (OfSTED) (1998) Framework for the Assessment of Quality and Standards in Initial Teacher Training. London: TTA/OfSTED.

Teacher Training Agency (TTA) (2002) Qualifying to Teach: Standards for the Award of Qualified Teacher Status. London: TTA. 
Training and Development Agency for Schools (TDA) (2007) Standards for the recommendation for Qualified Teacher Status (QTS). London: TDA.

Van Eman, L., Thorman, J., Montgomery, D. and Otto, S. (2008) The Balancing Act: Arts Integration and High-Stakes Testing, Journal for Learning through the Arts: A Research Journal on Arts Integration in Schools and Communities, 4(1). (Available online: http://repositories.cdlib.org/clta/lta/vol4/iss1/art7. Accessed 31.3.09).

Wilson, A. (ed.) (2005) Creativity in Primary Education. Exeter: Learning Matters. 